\title{
FINANCING HEALTH CARE AND THE EFFECT OF THE TAX LAW*
}

\author{
ROBERT S. BROMBERG $\dagger$
}

INTRODUCTION

This article is a study in cause and effect. Its thesis is a simple one. On the one hand, the federal income tax laws, by providing tax exemption and encouraging contributions to qualifying nonprofit health institutions, have an important effect on the operation and expansion of our voluntary hospitals, homes for the aged and other health facilities. On the other hand, the changing patterns of financing health care have an equally important effect upon the laws which provide tax exemption for these institutions. Particularly in recent years, the methods by which health institutions now finance the care they provide have led to sharp growing pains in the developing law of charitable exemption.

This article will therefore attempt to (1) place the significance of the benefits of tax exemption to health institutions in its proper perspective, and (2) trace the effect of the changing patterns of financing health care upon the ability of such institutions to qualify for these benefits under a body of law which is going through a period of readjustment. Although the discussion will focus on voluntary nonprofit hospitals, where the battle has recently been most hotly contested, many of the concepts set forth have equal applicability to homes for the aged, nursing homes, extended care facilities, clinics, health maintenance organizations, and other forms of nonprofit health institutions.

\section{I}

\section{The IMPORTANCE OF TAX EXEMPTION}

There are many reasons why it is important that voluntary nonprofit hospitals be recognized as organizations described in section 501(c)(3) of the Internal Revenue Code of 1954. The basic exemption from federal income tax is provided under section 501(c)(3) of the Internal Revenue Code which covers organizations "organized and operated exclusively for religious, charitable, scientific, testing for public safety, literary or educational purposes or for the

* 1976 by the author.

+ Baker, Hostetler \& Patterson, Cleveland, Ohio; Special Tax Counsel to the American Hospital Association. 
prevention of cruelty to children, no part of the net earnings of which inures to the benefit of any private shareholder or individual." Contributions and bequests to this class of organizations are deductible under sections 170 , $545(\mathrm{~b})(2), 556(\mathrm{~b})(2), 642(\mathrm{c}), 2055,2106(\mathrm{a})(2)$, and 2522 of the Code-the various income, estate and gift tax sections provided for deductibility of charitable contributions.

\section{A. Exemption From Income Tax}

The first and most obvious advantage of tax exemption under section $501(\mathrm{c})(3)$ is freedom from federal income tax. ${ }^{1}$ In order to remain financially solvent, it is usually necessary for most hospitals to attempt to operate at an excess of receipts over the sum of disbursements and historical cost depreciation. Under cost reimbursement formulae, replacement and renovation of assets is generally limited to reimbursement based on depreciation, with most "cost plus" exceptions usually being inadequate in inflationary periods. Depreciation expense is generally calculated to recover the cost of an asset through cash reimbursement by the end of the asset's estimated useful life. However, in today's inflationary economy, this formula will obviously not be sufficient to enable hospitals to replace assets at current prices. Thus, inflation, coupled with technological advances which make needed replacements more complex and expensive, makes it difficult for hospitals to rely on reimbursement for their future capital needs and compels them to orient their operations toward realizing an excess of receipts over disbursements just to operate. Thus, "profits" in the accounting sense are necessary for the modern hospital in order to provide the facilities and services demanded by the public.

At the same time, it is "profits" in the accounting sense which are taxed under the tax laws. Thus, exemption under section 501(c)(3) is a valuable aid to many nonprofit hospitals striving to satisfy the community's demand for newer and better services and facilities. Nevertheless, as will be noted later, it is often the presence of these paper "profits" that conflicts with the superannuated image of the nonprofit hospital as an organization operating in the red and subsidized by philanthropy. ${ }^{2}$

1. INT. Rev. Code of 1954, \$ 50l(c)(3). Although exemption from federal income tax is also available under other paragraphs of section $501(\mathrm{c})$, particularly under the social welfare exemption of section $501(\mathrm{c})(4)$, the author is not aware of any nonprofit hospital which, having been denied exemption under section $501(\mathrm{c})(3)$, has qualified for exemption under section $501(\mathrm{c})(4)$. If a hospital fails to qualify under section 50 l(c)(3), the IRS might take the position that the disqualifying factors in the case also preclude the hospital from operating exclusively for the promotion of social welfare under section $501(c)(4)$. although the different standards for exemption under these two sections might not support such a position.

2. See, e.g., Mayor of Vicksburg v. Vicksburg Sanitarium, 117 Miss. 709, 78 So. 702 (1918); O'Brien v. Physicians Hospital Ass'n, 96 Ohio St. 1, 116 N.E. 975 (1917). 


\section{B. Contributions}

Another and even more significant advantage of exemption under section $501(c)(3)$ is that the organization will normally qualify to receive contributions deductible for federal income, gift, and estate taxation. Although philanthropy in the eighteenth and nineteenth centuries often provided the necessary operating funds for the day-to-day operations of nonprofit hospitals, the role of philanthropy today has been radically changed, but has not diminished in importance. Philanthropy in the 1970's remains a vital force in the capital financing of American hospitals. ${ }^{3}$

Philanthropy continues to play an important role in health care. In 1972 philanthropists provided more than $4 \%$ of total health costs and about $30 \%$ of private construction costs. Dollar contributions to health during the year increased to an estimated 3.68 billion dollars.

Other estimates support this statement and indicate that philanthropy has continued to provide a substantial part of the capital needed by our hospitals for expansion and modernization. ${ }^{4}$

At the turn of the 20th Century, most of the funds required for hospital construction and/or modernization were provided through fund raising programs. The total amount of funds furnished through philanthropy has continued to increase.

During recent decades, the hospital industry has experienced some degree of criticism directed against the unnecessary expansion and construction of hospital facilities. It is therefore important to observe that this problem has abated and today's capital funds are being applied not primarily to the construction of new hospitals, but to the renovation and modernization of existing ones. Comprehensive and regional health planning agencies have made important strides toward eliminating unnecessary construction. However, renovation and modernization of existing facilities has become more important than ever. ${ }^{5}$

The primary ... [reason] is the inevitable obsolescence of facilities. Advances in medical science demand the development of more sophisticated accomodations, such as intensive care and/or cardiac care units. Evolutions in the patterns of care demand less sophisticated facilities, such as extended care beds and enlarged or renovated ambulatory care departments. Technological advances in the ancillary services also require that these departments be brought up to date. And patients are demanding private rooms and bathroom facilities, thereby provoking a reduction in multibed wards. In summation of these forces of change, hospitals must confront the inexorable demands of time, which insist that nonconforming facilities be made contemporary.

3. American Hospital Ass'n Fund Raising Council, Giving U.S.A.: 1973 Annual Report 34 (1973) [hereinafter cited as Giving U.S.A.].

4. Ackerman, Obtaining Capital Funds for Modernization, 48 Hospitals no. 3, at 59 (1974).

5. Editorial Note, Renovation Projects Swell Total of Hospital Constructions, 48 Hospitals no. 3, at 51 (1974). See also Pierson, An Examination of Obsolescence, 48 Hospitals no. 3, at 52 (1974). 
Another important dimension to philanthropy is that it provides needed funds for the development of research and new techniques and services. In a recent speech, Dr. Charles C. Edwards, Assistant Secretary of the Department of Health, Education and Welfare stated: "The kind of activities made possible through philanthropic donations and private grants are likely to represent innovations in both research and services, for which Federal dollars are often not available." Thus, there can be little doubt that the tax laws have a strong and positive impact on nonprofit hospitals by encouraging charitable contributions.

\section{Other Benefits}

Some of the other benefits from tax exemption can be briefly discussed. First, there is the freedom from a variety of other federal taxes. ${ }^{7}$ Second, exempt hospitals can provide their employees with the so-called "tax sheltered annuities" under section 403(b), enabling them to attract and hold a higher caliber of personnel. ${ }^{8}$ Finally, there is an overlap between the exemption from federal income tax under section $501(\mathrm{c})(3)$ and the exemption from ad valorem (real property) taxes in many states. ${ }^{9}$ Although a decision on a hospital's qualification as a charitable institution in one jurisdiction is not binding upon all others, ${ }^{10}$ many states' authorities and courts give recognition to the federal rules. ${ }^{11}$

A hospital's inability to qualify under section 501(c)(3) can often affect its real property exemption at the state level. In the recent ad valorem case of Jackson County $\%$. State Tax Commission, ${ }^{12}$ the lower court made specific reference to the criteria for tax exemption under federal tax law in denying real and personal property tax exemption to three hospitals in Kansas City, Missouri. For all of these reasons, qualification as a section 501 (c)(3) organization has an important effect on voluntary, nonprofit hospitals. Therefore any rules which unreasonably prevent hospitals from qualifying for exemption may have a serious adverse impact on the ability of these institutions to deliver the kind of care and treatment desired by the public. ${ }^{13}$

6. Address before Presbyterian-University of Pennsylvania Medical Center's Annual Recognition Dinner, Philadelphia, Pa., Nov. 19, 1974.

7. See, e.g., Rev. Rul. 74-537, 1974 Int. Rev. Bull. No. 44, at 14.

8. Azad v. United States, 388 F.2d 74 (8th Cir. 1968); Vincent M. Ravel, 26 CCH Tax Ct. Mem. 885 (1967).

9. See Jackson County v. State Tax Comm'n, 521 S.W.2d 378 (Mo. 1975).

10. Universal Life Church v. United States, 372 F. Supp. 770 (E.D. Cal. 1974).

11. See, e.g., Jackson County v. State Tax Comm'n, 521 S.W.2d at 378.

12. See id.

13. On the other hand the study of Martin Feldstein and Elizabeth Allison suggests that tax subsidies inflate the value of health services, reduce the efficiency of the health care delivery system and inequitably directs the major share of the subsidy to relatively higher-income families. Thus, it might well be that the increasingly sophisticated, high-cost health care is in fact a desire 


\section{A. Historical Background}

Although the demand for philanthropy has remained high, its role in the financing of health care has shifted to reflect the changing role of the nonprofit hospital itself. In order to appreciate the controversy over the criteria for tax exemption of charitable hospitals in recent years, the dramatic change in the nature and function of our hospitals must first be understood. The image of the "charitable hospital" has its origins in the eighteenth and nineteenth centuries where nonprofit hospitals were institutions primarily engaged in providing free care for the poor. This care was usually underwritten by philanthropy and by charging pay patients far in excess of the cost of their care in order to produce a sufficient surplus to underwrite the care of those unable to pay. Initially, the hospital was principally a custodial institution for unwanted members of society-the sick, the poor, the wanderers, the displaced, the incurables, and the infectious. ${ }^{14}$

The oldest known hospital in western Europe was the Hotel Dieu founded at Léone in 542 A.D. It served as an inn, workhouse, asylum, and infirmary. Its principal purpose was to serve the indigent, with provision of medical care being incidental. The first American hospital was the Philadelphia General Hospital, which grew out of the Phildelphia Almshouse founded in 1713. It, and its immediate successors, were essentially almshouses and provided facilities for indigents, criminals, foundlings, the physically handicapped, and the mentally unbalanced. ${ }^{15}$

General hospitals were established in the United States as early as the 18th Century to serve the sick poor, and offer a roof and bed for the homeless or for those whose homes were inadequate. These institutions were primarily the last resort of the sick. Their standards of care did not approach those for the simplest custodial care today. Hospital cleanliness was unknown, nursing was unskilled, the equipment did not even include the clinical thermometer.

\section{B. Basic Changes}

Toward the end of the nineteenth century and into the twentieth century, with the introduction of asepsis and anesthesia, the development of diagnostic procedures, specialization, expert nursing services, clinical laboratory services,

of a relatively small portion of the American public. See Staff of Jont Economic Comm.. 93d Cong., 2d Sess., The Economics of Federal. Subsidy Programs 977, 984 (Comm. Print 1974).

14. See J. Letourneau. Hospital Trusteeship Commission on Hospital Care 4 (1959); Commission on Hospital Care, Hospital Care in the United States 425 (1947); J. Knowles, Hospitals, Doctors and the Public lnterest 9 (1965).

15. I Financing hospital Care in the United States, factors affecting the Cost of Hospital Care 9 (J. Hayes ed. 1954) [hereinafter cited as Hospital Care]. See also Bromberg, The Charitable Hospital, 20 Catholic U.L. Rev. 239 (1970). 
and $\mathrm{x}$-ray and antibiotics, the hospital began to evolve into its present position as "the community centralized facility for medical care." 6

Philanthropy provided the initial means of funding free care in the eighteenth and early nineteenth century hospitals, but charging pay patients in excess of cost later became equally important. As the hospitals evolved from almshouses to community health facilities, a number of important changes were also incurred in the method of financing hospital care, including: (1) a steady increase in patient income, with a corresponding increase in the percentage of expenses covered by revenues from pay patients, as compared to revenues from charitable contributions; ${ }^{17}$ (2) a substantial increase in the cost of hospital care because of higher wages and improved technology: ${ }^{18}$ (3) the rapid growth of health insurance to meet the increasing costs of hospital and medical care; ${ }^{19}$ (4) the provision of health insurance coverage for the poor under Medicare and Medicaid (with a program of national health insurance on the horizon) $;^{20}$ and (5) a resulting decline in the portion of free or belowcost patients requiring hospital care. ${ }^{21}$ In summation, the early image of the nonprofit hospital as primarily concerned with free care to indigent persons is no longer applicable to the modern hospital. Health insurance has become sufficiently widespread to cover all but a small fraction of our population, with state and federal governments now paying for most indigent care. ${ }^{22}$

At the same time, while there are still persons for whom no reimbursement is available, the hospital's ability to finance the cost of free care for this group is sharply diminished. Although philanthropy once paid for most free care, by 1972 it provided less than four per cent of the total health care costs for all operating purposes. ${ }^{23}$ Hospitals no longer rely on philanthropy to cover the costs of such free care as may still be required. ${ }^{24}$ As recently indi-

16. R. Brown, A Current Evaluation of Hospital Planning Principles for Planing the Future Hospital. System (1959). "The modern hospital can scarcely be recognized as the offspring of the almshouse and the pest house of the 18 th Century." G. Rosenthal, The Demand for General Hospital Facilities 3 (1964).

17. J. Hayes, Clinics, Hospitals, and Health Centers 13 (1927); Hospital Care 53, 60-61.

18. R. Baehr, Medical Care in Transitiox 326 (1967): Department of Health, Education and Welfare. Report of Secretary's Advisory Comm. on Hospital Effectiveness 6 (1968).

19. By 1940 only about 9 per cent of our population had some form of hospital insurance. However by 1973, over 95 per cent of our civilian population was covered by some form of health insurance or otherwise was not medically indigent. See H. KLARMAN, The Economics of HeALTH 31 (1965).

20. See H.R. 13870, 93d Cong., 2d Sess. (1974) ("Kennedy-Mills" bill); H.R. 12684, 93d Cong., 2d Sess. (1974) ("Nixon Administration" bill); S. 2970, 93d Cong., 2d Sess. (1974); H.R. 1, 93d Cong., 2d Sess. (1974) ("Ullman" bill).

21. Hospital Care 56.

22. Worthington, National Health Expenditures 1929-1974, 38 Social SEc. Bull. no. 3, at 10 Table 3 (1975),

23. Giving: U.S.A. 34.

24. "The image of a voluntary institution as a charitable organization, financing its care of patients to a substantial degree through philanthropy ... is largely anachronistic. Philanthropy, though increasing, has not been able to match the redoubled demands for health care." State- 
cated in Business Week, "[m]any big city hospitals carry a crushing burden beyond relief by either philanthropy or continual rate increases." 25 Furthermore, "the need for capital is outstripping the philanthropy supply." 26 Although donors still make contributions earmarked for building funds and medical education and research, government programs such as Medicare and Medicaid have dampened philanthropy. "Many private givers have turned to other philanthropies under the impression that the government was now paying the hospital bill."27

The hospital's ability to finance free care through the other traditional means of shifting the burdens to patients paying more than the cost of their own hospital care has also diminished. Medicare and Medicaid universally, and Blue Cross plans generally, provide reimbursement on the basis of cost, while only commercial plans and self-pay patients pay in excess of cost. However the percentage of hospital expenditures which are reimbursed on the basis of cost, leaving no excess to cover the cost of charitable care, is steadily increasing, rising from 68.2 per cent in 1970 to 72.8 per cent in $1972 .{ }^{28}$ Thus, if patients paying charges would be required to shoulder the entire burden of the cost of indigent care, an unfair and intolerable burden would be placed on the 27.2 per cent of our patient population.

\section{III}

\section{Revenue Ruling 56-185 and the Relief of Poverty Theory}

The relief of poverty theory for exemption of nonprofit hospitals and homes for the aged grew up in a response to the historic origins of these institutions. This theory predicates tax exemption of hospitals and old age homes on the grounds that by providing free care to indigent patients, they are relieving the burden of government and doing charity in the "almsgiving" sense. Typical of this approach is the 1917 case of O'Brien $v$. Physician's Hospital Association ${ }^{29}$ in which the Supreme Court of Ohio stated that: "The first concern of a public charitable hospital must be for those who are unable to pay." 30 The analogy between the charitable hospital and the almshouse can be found as late as 1926: "A public hospital is a charitable institution, and

ment of William Thomas, Hearings on Conditions and Problems of the Nation's Nursing Homes, Before a Subcomm. of the Special Senate Comm. on Aging, 89th Cong., 1st Sess., pt. 2, at 559 (1965). See also Eastern Kentucky Welfare Rights Organization v. Simon. 506 F.2d 1278, 1288 n. 20 (D.C. Cir. 1974).

25. Business WeEk, October 26, 1974, at 118.

26. Walls, Cost Reimbursement Worsens Capital Crisis, 46 Hospitals no. 5, at 81 (1972).

27. Business WEEK, supra note 25, at 118.

28. American Hospital Association, 1973 american Hospital Ass's Guide to the Health CARE FIELd (1973).

29. 96 Ohio St. 1, 116 N.E. 975 (1917). See also Mayor of Vicksburg v. Vicksburg Sanitarium, 117 Misc. 709, 78 So. 702 (1918).

30. 96 Ohio St. at 9, 116 N.E. at 977. 
under some statutes, an almshouse, so as to be exempt from taxation; but not so if it is entirely self-supporting." ${ }^{31}$

The embodiment of the relief of poverty theory of tax exemption, with its emphasis on the provision of free or below-cost care for the poor, is Revenue Ruling 56-185. ${ }^{32}$ Although this Ruling sets forth various criteria for tax exemption, many of which are patently contradictory, it has for many years been interpreted to establish as the principal criterion for exemption under section 501(c)(3) the requirement that a hospital "must be operated to the extent of its financial ability for those not able to pay for the services rendered and not exclusively for those that are able and expected to pay." 33

This basic requirement was consistent with the origin and early development of charitable hospitals. Nevertheless, the Ruling contained many serious internal inconsistencies and was totally inadequate in providing criteria for a nonprofit hospital in the 1970 's. It fails to take into account the many vital changes that had taken place in the law of charity, as well as in the Income Tax Regulations interpreting section 501(c)(3). The Ruling recognizes that a hospital may be exempt under section $501(\mathrm{c})(3)$ because it is "organized and operated primarily for educational, scientific or public charitable purposes." Theoretically, a nonprofit hospital may therefore be exempt under Revenue Ruling 56-185 by conducting medical education, training, or research. The recognition of these alternate grounds for exemption is in sharp contrast to the very narrow definition of charity set forth in other parts of the Ruling. The confusion engendered by this ambivalence created difficulties in application of the Ruling, leading to IRS challenges to the exempt status of various hospitals and uneven administration of the law. Furthermore, although an exempt hospital was required under Revenue Ruling 56-185 to operate "to the extent of its financial ability for those unable to pay", the Ruling contained a number of significant modifications, making its administration even more uncertain. ${ }^{34}$

31. Southwestern Osteopathic Sanitarium v. Davis, 115 Okla. 296, 297, 242 P. 1033, 1034 (1926). For a general discussion of the relief of poverty versus the humanitarian (or community benefit) approach to tax exemption, see Bromberg, Charity and Change: Current Problems of Tax Exempt Health and Welfare Organizations in Perspective, in Tax Problems of Non-Profit Organizations 1970, at 253-56 (G. Webster \& W. Lehrfeld eds. 1970): Bromberg. The Charitable Hospital. 20 Catholic U.L. Rev. 237. $241-44$ (1970): Fowler. Humanitarian Approach to Taxation of Homes for the Aged. 21 Willamette L.J. 501 (1968): Note, Exemptions of Educational, Philanthropic and Religious Institutions From State Real Property Taxes. 64 Harv. L. Rev. 288 (1950); Note, Charitable Exemptions From Real Estate, 17 DEPAUL L. REv. 433 (1968).

32. 1956-1 Cum. Buls. 202.

33. Id. See also Comment, Federal Income Tax Exemption for Private Hospitals, 36 FordHam L. Rev. 747 (1968).

34. Revenue Ruling 56-185 modified the financial ability standard as follows:

The fact that its charity record is relatively low is not conclusive that a hospital is not operated for charitable purposes to the full extent of its financial ability. . . It may also set aside earnings which it uses for improvements and additions to hospital facilities. . . 
Revenue Ruling 56-185 was inadequate not only in failing to account for the changing patterns in financing health care discussed above, but also in failing to provide ascertainable standards for administration. Its imprecise standards "resulted in significant uncertainty of the extent to which a hospital must accept patients who are unable to pay, in order to retain its exempt status." 35 These inadequacies were subsequently confronted by the publication of Revenue Ruling 69-545, ${ }^{36}$ which provided alternative, but more ascertainable standards for exemption of nonprofit hospitals under section 501(c)(3), which shifted the charitable emphasis from relief of the poor to the more dynamic concept of general community welfare standards which reflected the realities of hospital operations in this decade. ${ }^{37}$

\section{IV}

\section{Revenue Ruling 69-545 ANd the Community Benefit Theory}

\section{A. Regulatory Background}

In addition to the administrative problems created by Revenue Ruling 56-185 and the fact that the Ruling was out of tune with the realities of modern health care, there was another compelling reason for the IRS to reconsider the criteria for charitable qualification of nonprofit hospitals set forth in the 1956 Ruling. After the enactment of the Internal Revenue Code of 1954 , the Treasury Department undertook to issue new Regulations under section $501(c)(3)$. The Regulations under the 1939 Code in effect at that time and during the issuance of Revenue Ruling 56-185 stated: "Corporations organized and operated exclusively for charitable purposes comprise, in general, organizations for the relief of the poor." 38

Proposed Regulations, initially issued in 1956, basically repeated this restrictive view of charity, but were withdrawn while a more extensive study was made. The first comprehensive set of Regulations interpreting section $501(c)(3)$ were proposed early in $1959^{39}$ and after public hearings, final Regu-

A nominal charity record for a given period of time, in the absence of charitable demands of the community, will not affect its right to continued exemption.

Rev. Rul. 185, 1956-I Cum. Bull. 202. Further, as noted by the court of appeals in Eastern Kentucky Welfare Rights Organization v. Simon, 506 F.2d at 1289 n. 26: "Hospitals operating at a deficit would have no obligation under Ruling 56-185."

35. H.R. ReP. No. 413,91st Cong., 1st Sess. pt. 1, at 43 (1969).

36. 1969-2 Cum. Bull. 117.

37. The Supreme Court in Memorial Hospital v. Maricopa County, 415 U.S. 250 (1974), in referring to "the astronomical costs of hospitalization which bear so heavily on the resources of most Americans" recognized the fact that the "financial pressures under which private nonprofit hospitals operate have already led many of them to turn away patients who cannot pay or to severely limit the number of indigents they will admit." Id. at 265 .

38. Treas. Reg. 118, §39.101(6)-1(b) (1953).

39. 24 Fed. Reg. 1421 (1959). 
lations were issued in 1959.41 These Regulations adopted a broader concept of charity than was found under prior Regulations. The principal provision defines the term "charitable" as follows:41

The term "charitable" is used in section 501(c)(3) in its generally accepted legal sense, and is, therefore, not to be construed as limited by the separate enumerations in section 501 (c)(3) of other tax exempt purposes which may fall within the broad outlines of "charity" as developed by judicial decisions. Such term includes: relief of the poor and distressed or of the underprivileged; advancement of religion; advancement of education or science; erection or maintenance of public buildings, monuments or works; lessening of the burdens of government; and promotion of social welfare by organizations designed to accomplish any of the above purposes, or (i) to lessen neighborhood tensions; (ii) to eliminate prejudice and discrimination; (iii) to defend human and civil rights secured by law; or (iv) to combat community deterioration and juvenile delinquency.

Under these 1959 Regulations, the term "charitable" is obviously not limited to relief of poverty, but encompasses a broad concept of community benefit or public interest. The recognition of the broad concept of the law of charity in the 1959 Regulations required a reexamination of Revenue Ruling 56-185 which had been issued three years earlier under the prior Regulations.

\section{B. Legal Basis}

Turning now to the controversial Revenue Ruling 69-545, it is at once obvious that the promulgation of this Ruling represents a serious attempt by the service to (1) solve the administrative difficulties of Revenue Ruling 56-185; (2) provide rules for qualification of tax exempt hospitals which are consonant with the realities of their operation and financing; and (3) bring the criteria for exemption of nonprofit hospitals into phase with the broader interpretation of the term "charitable" set forth in the 1959 Regulations. Because of the challenge to Revenue Ruling 69-545 raised in the case of Eastern Kentucky Welfare Rights Orgamization 7 . Simon, ${ }^{42}$ it is important to examine carefully the legal basis for this Ruling.

The rationale of Revenue Ruling $69-545$ is based upon the proposition in the Regulations that the term "charitable" must be interpreted in its generally accepted legal sense, ${ }^{43}$ which is broad and comprehensive and has been so for centuries. ${ }^{44}$ One of the long recognized definitions of charitable purposes encompasses the concept of community benefit. ${ }^{45}$ In addition to the relief of

40. 24 Fed. Reg. 5217 (1959).

41. Treas. Reg. $\S 1.501(c)(3)-(1)(d)(2)(1960)$.

42. 506 F.2d 1278 (D.C. Cir. 1974).

43. See Greene v. Connally, 330 F. Supp. 1150,1157 (D.D.C. 1971), affd per curiam sub nom.

Coit v. Greene, 404 U.S. 997 (1971).

44. Reiling, What is a Charitable Organization?, 44 A.B.A.J. 525,527 (1958).

45. See 330 F. Supp. 1150,1158 (D.D.C. 1971). See also A. ScotT. The LAw of Trusts $\$ 374$ 
poverty, the advancement of education, and the advancement of religion, there is a fourth principal heading of charitable purposes consisting of those which are "beneficial to the community." 46 Promotion of health has traditionally been recognized as constituting either a purpose which is "beneficial to the community" 47 or as a separate fifth heading of charitable purposes. ${ }^{48}$

The legal cornerstone for treating promotion of health as a charitable purpose, as indicated in Revenue Ruling 69-545, is the recognition that charity extends to the relief of distress and affliction, and is not limited to relief of poverty. ${ }^{49}$ This principle antedates the enactment of the first charitable exemption of the 1909 Act. ${ }^{50}$ Perhaps the most frequently quoted expression of this principle is that the "[r]elief of poverty is not a condition of charitable assistance. If the benefit conferred is of sufficiently widespread social value, a charitable purpose exists." 11 In more recent times, Professor Scott has observed that, "[a] trust for the promotion of health, however, is nonetheless charitable even though benefits are not limited to the poor.," 52

Revenue Ruling 69-545 recognizes this principle by stating: ${ }^{53}$

In the general law of charity, the promotion of health is considered to be a charitable purpose. . . A nonprofit organization whose purpose and activity are providing hospital care is promoting health, and may, therefore, qualify as organized and operated in furtherance of a charitable purpose.

However, it goes on to set forth certain criteria as evidence that certain kinds of exempt hospitals will, in fact, benefit the community. Under Revenue Ruling 69-545, one way a nonprofit hospital will be considered as benefiting the community is to (a) operate an emergency room for all persons regardless of

(3d ed. 1967); G. Bogert, The Law of Trusts and Trustees $\$ 363$ (2d ed. 1960); s'f Brunvate, The Legal Definition of Charity, 61 LAw Q. Rev. 268 (1945).

46. Lord McNaghton's definition in Special Comm'rs v. Pemsel [1891] A.C. 531, 3 G.B. Tax Cases 53, 96, cited by Justice White in Evans v. Newton, 382 U.S. 296, $307-08$ (1966).

47. Jackson v. Phillips, 96 Mass. (14 Allen) 539, 556 (1867).

48. Restatement (Second) of Trusts $\$ 368$ (1959).

49. "Although the relief of the poor. or benefit $t$ them is, in its popular sense a necessary ingredient in the chairty. this is not so in the view of the law." (. \%olluax. Americax Law of Charity $135-36$ (1924).

50. Ch. 6, 36 Stat. 11 (1909). "It is a general rule in the construction of exemptions from taxation that the word 'charity' is not to be restricted to the relief of the sick or the poor, but extends to any form of philanthropic endeavor or public benefit." H. Black, A Treatise IN the Law of Income Taxation 40 (2d ed. 1950); 84 C.J.S., Taxation \$ 282, at 543 (1954). Sep also Gerke v. Purcell, 25 Ohio St. 229 (1875).

51. In re Estate of Henderson, 17 Cal. 2d 853.857. 112 P.2d 605. 607 (1941). See also RestaTEMeNT (Second) of Trusts, supra note 48. $\$ \$ 368.374$. People v. Cogswell, 113 Cal. 129.45 P. 270 (1896); Community Memorial Hosp. v. City of Moberly, 422 S.W.2d 290 (Mo. Sup. Ci. 1967); In w Estate of Rust, 168 Wash. 344,12 P.2d 396 (1932).

52. A. Scott, The Iaw of Trusts $\$ 372$. al 2895 , $\$ 368$, at 2853 (3d ed. 1967). See also G. BockRT, supra note 45. \$ 374, at 107: Sacks. The Role of Philombropy: An Institutional View, 46 VA. L. RFv. $516,518(1960)$.

53. 1969-2 CuM. Bul.L. 117. 
ability to pay and (b) provide hospital care for those persons in the community able to pay the cost thereof, directly or through third party reimbursement, such as through Medicare or Medicaid.

Because the promotion of health is a charitable purpose, countless legal authorities have concluded that a nonprofit hospital, free of the taint of private benefit, is a charitable organization. ${ }^{54}$ While Revenue Ruling 69-545 actually goes beyond this proposition by requiring that hospitals seeking to qualify under its safe haven rule provide emergency room care for all and hospital care for Medicare and Medicaid patients, the legal recognition that a nonprofit hospital is charitable per se, without regard to the amount of free care delivered, provides a sound legal basis for Revenue Ruling 69-545.

Perhaps the most important aspect of Revenue Ruling 69-545 is its statement: "Revenue Ruling 56-185 is hereby modified to remove therefrom the requirements relating to caring for patients without charge or at rates below cost." This action is consonant with long-standing principles in both English and American law of charity. ${ }^{55}$ English law has long interpreted the charitable purpose enumerated in the preamble to the Statute of Elizabeth" ${ }^{\mathbf{6}}$ as "relief of aged, impotent and poor people" in the disjunctive, thereby permitting a charitable trust to operate for the benefit of sick or aged persons without reference to their financial condition. ${ }^{57}$

American authorities have also recognized that "the test of a charitable institution in many jurisdictions is not the extent of the free services rendered, nor whether the patients pay more or less than the cost for the services, but whether those who operate it are doing so for private profit, directly or indirectly." 58 The free or below cost standard of Revenue Ruling 56-185, which was eliminated in Revenue Ruling 69-545, has been the subject of sharp attack. ${ }^{59}$ For example, the Supreme Court of Arizona has stated that, " $[t]$ he position that the test of a charitable institution is the extent of free

54. Evangelical Lutheran Good Samaritan Soc'y v. County of Gage, 181 Neb. 831, 151 N.W.2d 446 (1967); City of Richmond v. Richmond Memorial Hosp., 202 Va. 86, 116 S.E.2d 79, 84 (1960); Weiss v. Swedish Memorial Hosp., 16 Wash. 2d 446, 133 P.2d 978 (1943); People ex rel. Doctors Hosp. v. Sexton, 267 App. Div. 736, 48 N.Y.S.2d 201 (1944), aff d per curiam, 295 N.Y. 553, 64 N.E.2d 273 (1945).

55. See notes 51 and 52 supra.

56. Statute of Charitable Uises, 43 Eliz., c. 4 (1601).

57. See, e.g., In re Glyn, [1950] 510 Ch., L.T.R. (56 Pt. 2): In re Wall, 42 Ch. D. 510 (1889); In re Lucas, [1922] 2 Ch. D. 52; In re Bradbury, [1951] Ch., 1 L.T.R. 130; In re Robinson, [1951] 1 Ch. 98; In re Lewis, A.E.R. 254 (1954). See also 4 Halsbury's Law of England $\$ 492$ (3d ed. 1953); see Brunyate, supra note 45.

58. E. Hayt, L. Hayt, \& R. Groeschel, law of Hospital, Physician and Patient 65-68 (2d ed. 1952). See also Benton County v. Allen, 170 Ore. 481, 133 P.2d 991 (1973).

59. "To say that the test of a charitable hospital is the amount of free services rendered is to apply a standard which is impractical and unsound . . . Free service is not a prerequisite to tax exemption, and the legal meaning of charitable purposes is not limited to the care of the indigent." E. Hayt, L. Hayt, \& R. Groeschel, supra note 58, at 68. See also 1 Aspen Systems, Hospital law Manual 25 (1973). 
services rendered, is difficult of application and unsound in theory." ${ }^{\circ 0}$ For this reason, some courts have preferred the rule that "[w]ithout doing any free work of any kind, [a] hospital would still be a charitable corporation so long as its surplus income is applied to the support, maintenance, and enlargement of the hospital and its facilities." 1

\section{The Eastern Kentucky Case in the District Court}

In 1971 a suit, entitled Eastern Kentucky Welfare Rights Organization v. Shultz, ${ }^{62}$ was commenced in the District Court for the District of Columbia by a group of indigents and welfare rights organizations against the Secretary of Treasury and Commissioner of Internal Revenue. The suit sought revocation of Revenue Ruling 69-545. The district court, in the decision by Judge Parker in December, 1973, sustained the plaintiffs' motion for summary judgment. The issue of standing (which is beyond the scope of this article) was decided in favor of plaintiffs. ${ }^{63}$ The district court further held that Revenue Ruling 69-545 was inconsistent with the meaning of the term "charitable" as used in section 501(c)(3) of the Internal Revenue Code and its publication was, therefore, beyond the discretion of the Commissioner. In its decision, the court stated: ${ }^{64}$

The emphasis given by the I.R.S. to Scott's principles of trust law . . was misplaced and provides, even when taken into conjunction with Green, an insufficient basis, in view of prior legislative and judicial history, to justify the basic shift in policy.

In so stating, the district court accepted without question the proposition that "[a]ny discretion incorporated into the IRS's authority . . . is necessarily limited by the understanding that Congress, not the Treasury, is responsible for the formulation and institution of basic tax policy." 65

In refusing to recognize the applicability of the law of charity, the district court acted contrary to precedent in its own circuit. A three-judge court impaneled in the same district in Greene $"$. Connally ${ }^{66}$ stated that: ${ }^{67}$

[C]learly, the term "charitable" is used "in its generally legal sense," . . . and not in a street or popular sense (such as, e.g., benevolence to the poor and suffering) .... Thus "strong analogy" can be derived from the general common law of charitable trusts, at least for close interpretative questions.

60. Southern Methodist Hosp. \& Sanitorium of Tucson v. Wilson, 51 Ariz. 424, 431, 77 P.2d 458, 462 (1943). See also City of Richmond v. Richmond Memorial Hosp., 202 Va. 86, 116 S.E. 2d 79 (1960).

61. Weiss v. Swedish Hosp., 16 Wash. 2d 446, 451, 133 P.2d 978, 980 (1943); In re Estate of Henderson, 17 Cal. 2d 853, 112 P.2d 605, 608 (1941).

62. 370 F. Supp. 325 (D.D.C. 1973), aff'd sub nom. 506 F.2d 1278 (D.C. Cir. 1974).

63. 370 F. Supp. at 329-33.

64. 370 F. Supp. at 337 .

65. $370 \mathrm{~F}$. Supp. at 334 .

66. 330 F. Supp. 1150 (D.D.C. 1971).

67. 330 F. Supp. at 1157. 
In another case, the United States Court of Appeals for the District of Columbia, in interpreting the phrase "organized and operated exclusively for religious, charitable, scientific, literary or educational purposes" for purposes of section 1(b)(7) of the District of Columbia Unemployment Compensation Act, found a congressional intent "to apply the exemption to those organizations commonly designated charitable in the law of trusts. Consequently we may properly draw analogy from the trust cases." 68

The district court's opinion in Eastern Kentucky appears to be the first decision denying exemption under section 501(c)(3) exclusively on the basis that a nonprofit hospital, which is free of the taint of private profit, must render free care to qualify under section 501(c)(3). A careful reading of the federal cases cited by the district court in the Eastern Kentucky decision indicates that the IRS has never litigated a case involving a nonprofit hospital where the question of private benefit to the dominant group of physicians, shareholders or directors was not involved. Thus there is reason to believe that major emphasis in hospital cases should be given to whether those persons operating the hospital "were conducting it for their private profit or advantage." 69 This test is reflected in both Revenue Ruling 56-185 and Revenue Ruling 69-545, and the latter ruling specifically delineates circumstances under which exemption will be denied because of the presence of such private benefit.

The emphasis on private benefit is amply illustrated in two cases cited by the District Court of the Eastern District of Kentucky-Sonora Community Hospital v. Commissioner of Internal Revenue ${ }^{70}$ and Lorain Avenue Clinic $v$. Commissioner. ${ }^{71}$ Although mention was made in both cases of the level of charitable care, in neither case did the denial of exemption turn on the issue of free care. In both cases, there was strong evidence of other factors indicating the presence of substantial private benefit. The failure to provide any substantial amount of free care in these and other federal cases was merely further evidence that the parties controlling the hospitals were operating them for their private benefit. ${ }^{72}$ The only cases where the question of tax exemption of a nonprofit hospital has been litigated because of the question of the quantum of free care to be provided to persons unable to pay have

68. International Reform Fed'n v. District Unemployment Compensation Bd., 76 U.S. App. D.C. 282,284 (1942).

69. Southern Methodist Hosp. \& Sanitorium of Tucson v. Wilson, 51 Ariz. 424, 433, 77 P.2d 458, 462-63 (1943). See also In re Mendelson, 262 App. Div, 605, 31 N.Y.S.2d 431 (1941); Mac-

Donald v. Massachusetts General Hosp., 120 Mass. 432 (1876).

70. 46 T.C. 519 (1966), aff'd, 397 F.2d 814 (9th Cir. 1968).

71. 31 T.C. 141 (1958).

72. The other case cited by the district court was Commissioner v. Battle Creek, Inc., 216 F.2d 405 (5th Cir. 1942), which dealt with a hospital which had been organized under the general corporation laws of Florida, rather than nonprofit corporation laws, and was chartered to conduct any lawful business. The court in that case rejected the Service's argument that the hospital did not qualify as being organized exclusively for charitable purposes because of the business purposes which were authorized in its charter. 
been those cases making up the general law of charity, particularly the ad valorem tax exemption cases decided by our state courts. The overwhelming majority of these cases support the principles stated in Revenue Ruling $69-545 .^{73}$

The district court placed substantial reliance on prior legislative history to override the general law of charitable trusts. It first considered the Senate's consideration in 1924 of an amendment to section 214(a)(11) of the Revenue Act of 1918 and 1921, the predecessor of section $170(\mathrm{c})(2)(\mathrm{B})$ of the Internal Revenue Code of 1954. The purpose of this amendment, as characterized by the district court, was "to enable health service organizations to automatically qualify for the relevant tax considerations." 74 From the subsequent abandonment of this amendment by the Senate, the district court inferred a congressional intent to require hospitals to relieve poverty as a condition to charitable status. Unfortunately the court's characterization of the amendment proposed in 1924 by Senator Willis to H.R. $6715^{75}$ is not supported by its recorded history. Senator Willis specifically stated that the amendment was introduced "in order to draw the attention of the Senate to the dangerous situation in which the community chest funds will be if the bill shall pass in its present form."76 The amendment was made for the specific purpose of permitting community chest funds to operate for purposes "including preventive and constructive services for relief, rehabilitation, health, character building and citizenship." "77 Thus the court's characterization of community chest funds as "health service organizations" is clearly open to question, and the inference with respect to the validity of Revenue Ruling 69-545 drawn from the abandonment of the proposed amendments is without basis.

More important to the district court were the circumstances surrounding the elimination of a proposal contained in the House bill (H.R. 13270) of the Tax Reform Act of 1969 to exempt organizations "organized and operated exclusively for the providing of health care," the intention being to eliminate the necessity for providing free or below-cost care as a condition for exemption. The principal reason for this proposed legislation was the "significant uncertainty as to the extent to which a hospital must accept patients who are unable to pay, in order to retain its exempt status." 78

Thereafter, apparently in response to the suggestion of the Senate Finance Committee staff, the IRS promulgated Revenue Ruling 69-545, which set forth more certain and administrable standards for exemption of nonprofit

73. 1969-2 Cum. Bull. 117.

74. Eastern Kentucky Welfare Rights Organization v. Shultz, 370 F. Supp. 325, 331 (D.D.C $1973)$.

75. 65 Cong. Rec. 8171 (1924).

76. Id.

77. Id.

78. H.R. ReP. No. 413, 91 st Cong,, 1st Sess., pt. 1, at 43 (1969). 
hospitals. In considering the House bill, the Senate Finance Committee asked the staff of the Joint Committee on Internal Revenue to summarize arguments for and against the removal of the requirement of providing free or below-cost care for indigents. In concluding its summary the staff stated that: "Since the need for new legislative language has arisen because of uncertainties in administration, then the resolution of such uncertainties could be handled on an administrative basis." 79 The Senate Finance Committee then deleted the hospital exemption from H.R. 13270. In conference, the Senate version of the bill was accepted and the conference report noted that: ${ }^{80}$

The House Bill provides that hospitals, if they meet all the other requirements of Section 501(c)(3), are exempt under that provision, whether or not they provide charitable services on a non-cost or low-cost basis. The Senate amendment strikes out these provisions. The conference substitute . . follows the Senate amendments.

The district court read this legislative history as an indication that Congress believed that the old "relief of poverty" standard for exemption should continue to apply to charitable hospitals. It seems more likely, however, that it was simply avoiding resolution of the dispute which had already commenced concerning the validity of Revenue Ruling 69-545, preferring to leave the resolution of this question to the courts or to subsequent legislation.

It is also notable that Revenue Ruling 69-545, by referring to emergency care for all and hospital care for those able to pay, including Medicare and Medicaid patients, is more limited than the general provision of the proposed legislation which would have exempted all hospitals solely because they provide hospital care. Thus the failure to amend the code in the proposed way is not persuasive of congressional dissatisfaction with Revenue Ruling 69-545. Indeed it is better to consider that the failure of Congress to amend a statute is without meaning for purposes of statutory construction in a situation of this type. ${ }^{81}$

\section{Aftermath of Eastern Kentucky}

Following this success in the District Court for the District of Columbia, public interest and welfare rights lawyers began to prepare for additional litigation. Early in 1974 an article was published by Jeffrey Schwartz ${ }^{82}$ which provided strong encouragement for the commencement of actions against individual tax exempt hospitals for failing to provide enough free care to the poor. Causes of action based upon a tax exempt hospital's (1) failure to oper-

79. Summary of The Tax Reform Act of 1969, H.R. Rep. No. 13270, 91st Cong.. lst Sess. 24 (1969).

80. H.R. Rep. No. 782, 91 st Cong.. 1st Sess. 289-90 (1969).

81. Order of Ry. Conductors of America v. Swan, 329 U.S. 520,529 (1947).

82. Schwartz, Expanding the Quantity of Medical Services Available to the Poor: Suing the "Private" Hospitals Under the Internal Revenue Code, 7 Clearinghouse Rev. 587 (February 1974). 
ate for those unable to pay to the extent of its financial ability, (2) failure to provide emergency care, (3) failure to treat Medicare and Medicaid patients, and (4) racial discrimination were all suggested in the article and a complaint embodying these causes of action was advertised to readers of the Clearinghouse Review for twenty-five cents. ${ }^{83}$ The spring of 1974 saw these efforts bear fruit. Three actions were commenced against tax exempt hospitals in Massachusetts, Ohio, and New Mexico seeking a variety of relief. ${ }^{84}$ The causes of action included further attempts to invalidate Revenue Ruling $69-545$, as well as attempts to impose requirements for providing free care to indigents and to force hospitals not to bill persons allegedly unable to pay. No decisions have yet been reached in any of these cases.

\section{E. The Eastern Kentucky Case in the Court of Appeals}

On October 9, 1974, the United States Court of Appeals for the District of Columbia, by a two-to-two majority, reversed the district court and held that the promulgation of Revenue Ruling 69-545 was not an abuse of the commissioner's authority because it was founded on a permissible definition of the term "charitable." 85 The court of appeals, recognizing that both the promulgation in 1959 of new Regulations under section 501(c)(3), and broadening the definition of the term "charitable" as well as the general law of charitable trusts, provided an adequate basis for principles applied in Revenue Ruling 69-545, stating: " $^{6}$

The term "charitable" is thus capable of a definition far broader than merely the relief of the poor. The law of charitable trusts supports the broader concept. ...

... While it is true that in the past Congress and the federal courts have conditioned a hospital's charitable status on the level of free or below cost care that it provided for indigents, there is no authority for the conclusion that the determination of "charitable" status was always to be so limited. Such an inflexible construction fails to recognize the changing economic, social, and technological precepts and values of contemporary society.

The courts of appeals recognized the shift in the nature of nonprofit hospitals from yesterday's "almshouses supported by philanthropy and serving almost exclusively the sick poor" to today's "primary community health facility," 87 as well as the fact that the "institution of Medicare and Medicaid in the last decade, combined with the rapid growth of medical and hospital in-

\footnotetext{
83. Id.

84. Chapman v. Berkshire Medical Center, Civil No. 74-1954-F (D. Mass., June 6, 1974): Lugo v. Toledo Hosp., Civil No. $74-345$ (N.D. Ohio, Aug. 26, 1974).

85. Eastern Kentucky Welfare Rights Organization v. Simon, 506 F.2d 1278, 1290 (D.C. Cir. 1974).

86. 506 F.2d at $1287-88$.

87. 506 F.2d at 1288 .
} 
surance has greatly reduced the number of poor people requiring free or below-cost hospital services." 88 The court concluded that: ${ }^{89}$

The rationale upon which the limited definition of "charitable" was predicated has largely disappeared. To continue to base the "charitable" status of a hospital strictly on the relief it provides for the poor fails to account for these major changes in the area of health care.

The court of appeals took the position that: ${ }^{90}$

... Revenue Ruling 69-545 rather than overruling Revenue Ruling 56-185 simply provides an alternative method whereby a nonprofit hospital can qualify as a tax exempt charitable organization. That method entails the operation of an emergency room open to all regardless of their ability to pay and providing hospital services to those able to pay the cost either directly or through third party reimbursement.

However, while the court of appeals reversed the lower court on the question of the validity of Revenue Ruling 69-545, it nevertheless held against the government on the question of the standing of the plaintiffs to bring an action challenging the validity of a revenue ruling. This aspect of the court of appeal's decision is likely to be used by public interest and welfare rights groups as providing a basis for standing by persons allegedly unable to pay the cost of their hospital care to bring suit against individual tax exempt hospitals. The struggle of the nonprofit hospital to retain its tax exempt status is thus likely to shift ground from attack by the IRS to litigation commenced against individual hospitals by persons seeking an increase in the level of free care provided.

\section{$\mathrm{V}$ \\ Current Standards for Charitable Exemption}

The effect of the recent decision by the United States Court of Appeals for the District of Columbia in the Eastern Kentucky case is to permit a nonprofit hospital to qualify, or continue to qualify, as a charitable organization under section 501(c)(3) (absent any taint of private benefit) $)^{91}$ by satisfying either of two standards:

1. The Revenue Ruling $69-545$ (or Community Benefit) Standard: Benefiting the community by making available emergency room services to all and furnishing of other hospital services to patients able to pay, either directly or through third party reimbursement. (However, as indicated below, other evidence of community benefit should also qualify a hospital under this broad standard.)

88. Id.

89. 506 F.2d at $1288-89$.

90. 506 F.2d at 1289 .

91. See discussion of Harding Hospital, infra note 105. 
2. The Revenue Ruling 56-185 (or Financial Ability) Standard: Operating to the extent of its financial ability for those unable to pay.

\section{A. The Financial Ability Standard}

Since Revenue Ruling 69-545 merely modifies Revenue Ruling 56-185, it left the financial ability standard of the latter ruling intact as one method for a hospital to achieve exempt status. This was confirmed by dicta of the court of appeals in the Eastern Kentucky case. ${ }^{92}$

\section{Factors Determining Financial Ability}

It seems appropriate to conclude, as did the court of appeals in the Eastern Kentucky case, that most hospitals which operate at an annual expense over receipts deficit, particularly where the deficit is attributable to indigent care, would automatically be deemed in compliance with Revenue Ruling 56-185. However, this raises the question of what should be regarded as a deficit. For example, a deficit might be reflected in a hospital's annual financial statement, if based on its actual cash flow, not because it has no income in an accounting sense, but because the amortization of its indebtedness exceeds its depreciation deductions. It is arguable even in such case that the hospital has no financial ability to commit any further funds to free or below-cost care, and therefore, is operating in accordance with Revenue Ruling 56-185.

The court of appeals in Eastern Kentucky accepted the argument that the financial ability standard of Revenue Ruling 56-185 is a qualified one. If the cash-flow deficit occurs as the result of expenditures for capital improvements, this could well be adequate for meeting the financial ability test of Revenue Ruling 56-185, which states: ${ }^{93}$

The fact that its charity record is relatively low is not conclusive that a hospital is not operated for charitable purposes to the extent of its financial ability .... It may also set aside earnings it uses for improvements and additions to the hospital and its facilities. . . A nominal charity record for a given period of time, in the absence of charitable demands of the community, will not affect its right to continued exemption.

Revenue Ruling 56-185 is silent as to any percentage or fixed amount of free or below-cost care required of a tax exempt hospital. The percentages of free care found acceptable in earlier case law, incidentally involving cases where a private benefit was the primary issue such as Commissioner $v$. Battle Creek, ${ }^{94}$ David Hospital v. Commissioner, ${ }^{95}$ and Intercity Hospital Association $v$.

\footnotetext{
92. 506 F.2d at $1289-90$.

93. 506 F.2d at 1289 n. 26.

94. I26 F.2d 405 (5th Cir. 1942).

95. $4 \mathrm{CCH}$ Tax Ct. Mem. 312 (1945).
} 
Squire, ${ }^{96}$ were decided between 1942 and 1945. Assuming arguendo that the level of free care suggested in these cases is even relevant to the question of charitable exemption outside the context of private benefit, it should not remain the standard under today's conditions. In Battle Creek, out of 1,776 clinic patients, 705 were treated free and 145 paid a portion of the regular rate. ${ }^{97}$ Thus, 47 per cent of the patients treated were treated free or below-cost. In Davis Hospital, the hospital "received no compensation from any source for services rendered to $30 \%-40 \%$ of the patients admitted to and treated in this hospital."98 In Intercity Hospital Association, "an amount ranging from six to eight per cent of such gross income was donated to charity patients."99 Such discussions of free, or below-cost, care ranging from six to 47 per cent may have had some meaning for hospitals thirty years ago, but in view of the changed patterns in hospital financing and the substitution of reimbursement under Medicare, Medicaid and private hospital insurance, the levels of free care suggested in these earlier cases would seriously undermine the exempt status of most nonprofit hospitals today.

Furthermore, in determining whether a hospital is operating "to the extent of its financial ability" to provide services for those unable to pay (which includes medically indigent persons, ${ }^{100}$ as well as indigent ones), a number of other factors should be taken into consideration. Some of these factors are:

1. Medical education and training programs for interns, residents, nurses and paramedical personnel.

2. Medical research programs.

3. Replacement of obsolete, and acquisition of new, equipment.

4. Expansion of needed facilities and space.

5. Implementation or expansion of programs for the benefit of the community, e.g., mental health and drug abuse.

6. Payment of indebtedness on existing facilities or equipment.

7. Educational services for the community, e.g., inoculation or birth control programs.

8. Maintenance of reserves for physical expansion.

9. Availability of other community facilities providing services for indigents. This factor can be evidence of the limited demand for indigent services at a particular hospital. In this context, the importance of avoiding duplication of facilities should not be underestimated.

96. 56 F. Supp. 472 (W.D. Wash. 1944).

97. 126 F.2d at 406 .

98. See Rev. Rul. 124, 1972-1 Cum. Bull. 145.

99. 56 F. Supp. at 474 .

100. A medically indigent person is one who does not have sufficient funds to pay the cost of the particular hospital or medical care needed. Thus, a person in the middle or even upper middle class, depending upon his medical condition or the treatment required, could be medically indigent, although not indigent per se. 


\section{Forms of Charitable Care}

Although Revenue Ruling 56-185 appears to contemplate compliance with the financial ability standard in terms of free or below-cost care, it should be recognized that such care can be rendered in a number of ways.

The following are some of the facets of indigent care which any hospital whose exempt status is being questioned might advance as evidence of compliance with Revenue Ruling 56-185:

1. The excess of the cost of care provided over the charges made for such care and the percentages of total expenses and patient receipts attributable to the care resulting in such excess.

2. The operation of an emergency room and the loss attributable to emergency service. The absence of any requirement of a deposit for emergency care is also significant.

3. A policy of not bringing suit against medically indigent persons.

4. The write-off of uncollectible accounts as part of a hospital's charitable obligation. The concept held by many government officials and courts that it is possible to designate patients as "charity patients" on admission is often not feasible.

5. Losses on treatment of Medicare and particularly Medicaid patients, i.e., the difference between charges to self or commercially-insured patients and the reimbursement received under Medicare and Medicaid. ${ }^{101}$

6. Free or discount treatment rendered to employees, interns, residents, and clergy.

7. Expenses of research or educational programs which involve care of indigent patients.

8. Expenses of community health programs or projects.

B. The Community Benefit Standard

Both the court of appeals in Eastern Kentucky and the Internal Revenue Service take the position that Revenue Ruling 69-545 is an alternative means by which a hospital can qualify for tax exemption under section 501(c)(3). If a hospital meets the community benefit standard of Revenue Ruling 69-545, it is under no obligation to "operate to the extent of its financial ability" to provide services for indigent persons. In order to meet this alternative requirement, a nonprofit hospital must provide health services for the benefit of the community. Revenue Ruling 69-545 provides a safe haven rule under which a hospital is deemed to operate for the benefit of the community by providing (1) emergency services to all, regardless of ability to pay, and (2) hospital services to all persons able to pay, including Medicare and Medicaid

101. See Idaho Corp. v. Benedictine Sisters, Civil No. 1-72-169 (D. Idaho, Aug. 29, 1973); St. Mary's Hosp. of East St. Louis, Inc. v. Oglive, 496 F.2d 1324 (7th Cir. 1974). 
patients. The court in Eastern Kentucky has acknowledged the fact that these factors are a satisfactory, and in fact, more meaningful, method by which a charitable hospital can serve the public interest in this decade.

\section{Emergency Room Service}

One requirement under the safe haven rule of Revenue Ruling 69-545 is the operation of an emergency room open to all regardless of whether they can pay. Thus, requiring an advance deposit from a patient seeking emergency room care would not satisfy this requirement if patients unable to pay the deposit are refused treatment. Further, any policy by a hospital which results in local police, fire, or other ambulance services transporting needy persons requiring emergency care to other area institutions, would be damaging in the absence of mitigating circumstances. In such a case, however, a mitigating circumstance might be the operation by a hospital of an emergency room which has a heavy volume of, and is equipped to handle particular types of, emergencies, such as gunshot or stab wound cases, while an adjacent hospital's emergency room is not equipped with the personnel experienced to handle such cases and would, in fact, be unnecessarily duplicating the facilities of the municipal or teaching hospital if it attempted to provide such services. It should be noted, however, that a hospital which does not provide emergency services can nevertheless qualify for tax exemption by satisfying the requirements of Revenue Ruling 56-185 discussed above or by meeting other factors under an alternative community benefit approach discussed later.

\section{Services to Medicare and Medicaid Patients}

The other factor which must be met in order to satisfy the safe haven rule of Revenue Ruling 69-545 is that a hospital must provide hospital care for all persons in the community able to pay the cost thereof, either directly or through third party reimbursement. In particular, the hospital must accept Medicare and Medicaid patients. Therefore, a hospital seeking to qualify under Revenue Ruling 69-545 must not follow a policy of refusing to provide services for Medicaid patients, although it is not precluded from attempting to negotiate a favorable contract with the state for Medicaid reimbursement. However, if it discriminates against Medicaid (or Medicare) patients in its admissions policy, such as by screening out such persons and continually referring them elsewhere, the hospital will be vulnerable to a charge that it is not complying with the requirements of Revenue Ruling 69-545.

\section{Other Community Benefit Programs}

Although the court of appeals in Eastern Kentucky treats Revenue Rulings 56-185 and 69-545 as providing alternative methods for a nonprofit hospital 
to qualify for tax exemption, and has indicated that a tax exempt hospital "must still provide services to indigents," a nonprofit hospital should still be able to qualify under section 501 (c)(3) by making other forms of contribution to the community welfare. The Eastern Kentucky case indicates that these revenue rulings are only interpretative in nature and have no legally binding effect. ${ }^{102}$ This permits a nonprofit hospital to argue that it is still operating for the benefit of the community, but in some manner other than those specifically delineated by the IRS in Revenue Rulings 56-185 and 69-545.

The government, in its appellant's brief in Eastern Kentucky, has recognized that there are other ways of qualifying for tax exemption. In discussing the alternatives provided under Revenue Rulings 56-185 and 69-545, the government's brief states "of course, the way was left open for hospitals to qualify by implementing some other comparable programs of community benefit."103

Elsewhere in its brief, the government notes: ${ }^{104}$

In addition, Rev. Rul. 56-185 and Rev. Rul. $69-545$ must be viewed as what they are-separate approved modes of meeting the broad charitable trust standards-not as conflicting universal principles, each aimed at stating a universal all-encompassing charitable trust rule. For example, obviously the emergency room requirement could have little or no application to a number of kinds of hospitals such as a specialized cancer hospital.

\section{Approaches to Other Alternatives}

If a nonprofit hospital has difficulty in satisfying the standards of either Revenue Ruling 56-185 or Revenue Ruling 69-545, an alternative form of community benefit should be argued if the facts support such an approach. One form of community benefit would exist where the hospital is operating special facilities, programs, or projects which benefit the entire community, rich and poor alike. For example, a hospital which carries on extensive special research or medical programs in health areas of widespread interest or concern, develops or maintains extensive specialized equipment and facilities, or treats only specialized diseases, benefits rich and poor alike by the mere existence of its programs, even though it does not place great emphasis on indigent care. ${ }^{105}$ Similarly where the policy of local agencies is to limit and consolidate the number of emergency rooms, the absence of emergency care pursuant to such policy should not derogate from the value of a hospital to the community.

102. 506 F.2d 1278, 1290 (D.C. Cir. 1974).

103. Brief of Appellant at 80, Eastern Kentucky Welfare Rights Organization v. Simon, 506 F.2d 1278 (D.C. Cir. 1974).

104. Brief of Appellant at 72, Eastern Kentucky Welfare Rights Organization v. Simon, 506 F.2d 1278 (D.C. Cir. 1974).

105. But cf. Harding Hosp. v. United States, 505 F.2d 1068, 1076 n. 1 (6th Cir. 1974). 


\section{VI \\ Harding Hospital and Private Benefit}

Before closing this consideration of the criteria for tax exemption of nonprofit hospitals, some mention must be made of the Sixth Circuit Court of Appeals's decision in Harding Hospital $v$. United States, ${ }^{106}$ decided approximately one month after the decision of the Court of Appeals of the District of Columbia in Eastern Kentucky. In many ways, Harding Hospital is a most unfortunate decision. There is no question that the case would never have arisen, and been decided, if the issue of private benefit was not present. The operation of Harding Hospital was inextricably tied in with a medical partnership composed of seven doctors, all specialists in a particular form of psychiatric treatment known as milieu therapy. This group treated 90 to 95 per cent of all patients admitted to the hospital. The arrangements existing between the hospitals and the medical group were such as to warrant the IRS to propose revocation of its tax exempt status under section $501(\mathrm{c})(3)$ on the grounds that the hospital was operating for the private benefit of the medical group.

The Harding Hospital case is, therefore, in the same line of cases as Sonora Community Hospital, Lorain Avenue Clinic, and Maynard Hospital. ${ }^{107}$ In each of these cases, the controlling question was the presence and extent of private benefit. However, in each case the court, in determining whether the presence of private benefit precluded the hospital from operating "exclusively" for charitable purposes, considered the hospital's charity record. The reason for considering free care in these cases is obvious. If a hospital, controlled by a small group of physicians, did provide a substantial amount of free care, this would indicate that the controlling medical group is operating the hospital for the benefit of the public, rather than in their own interests. On the other hand, where the amount of free care provided is de minimus, it indicates that control by a small group is being used to maximize their own benefits.

Thus, at the outset, it is imperative to recognize that, unlike the Eastern Kentucky case which deals solely with the question of whether a nonprofit hospital must render "charity" in the alms-giving sense by providing free or low cost care to the poor in order to qualify for tax exemption under section 501 (c)(3), the Harding Hospital case deals primarily with the issue of whether the operation of a particular hospital is so suffused with the taint of private benefit to the controlling medical group as to disqualify it from tax exempt status. Although two out of the five factors considered by the Sixth Circuit in determining the exempt status of Harding Hospital involves some consideration

106. 505 F.2d 1068 (6th Cir. 1974).

107. Sonora Community Hosp. v. Commissioner, 46 T.C. 519 (1966), aff'd, 397 F.2d 814 (9th Cir. 1968); Lorain Avenue Clinic v. Commissioner, 31 T.C. 141 (1958); Maynard Hosp., Inc. v. Commissioner, 52 T.C. 1006 (1969). 
of free care, its consideration of these issues was still in the overall context of whether the hospital was exclusively charitable or was barred from such status by operating for the benefit of its founders.

The Sixth Circuit specifically indicated that: ${ }^{108}$

We find it unnecessary in the present case to pass judgment on the validity of Rev. Rul. 69-545. The issue was neither briefed nor argued before us. Further, the combination of fact set forth in $\S$ IV of this opinion requires denial of the tax exemption even if Rev. Rul. 69-545 should be determined to be valid.

Perhaps the strangest aspect of this case is that the Sixth Circuit did not directly make use of Revenue Ruling 69-545 since the hospital described as "Hospital B" in that revenue ruling has many striking similarities to the facts in the Harding Hospital case. Revenue Ruling 69-545 denies tax exemption to "Hospital B" because of the presence of private benefit. Thus, the Sixth Circuit Court of Appeals has apparently overlooked its basic agreement with Revenue Ruling 69-545's treatment of private benefit as incompatible with exemption under section 501(c)(3), although it still found Harding not to be exempt.

The court in Harding Hospital sets forth five factors as its basis for concluding that the hospital was not exempt under section 501(c)(3). However, it specifically stated that: ${ }^{109}$

We do not single out any one or combination of these factors as the consideration crucial to our holding. We conclude only that all these factors, as they occurred in the aggregate in this case, require denying the appellant Hospital the tax exemption for the years in question.

These factors are as follows:

1. There was insufficient evidence that the hospital "held itself out to the public even in the limited way as a charitable institution." 110 This conclusion is drawn from the fact that the only significant charitable donations which the hospital received during the years in question were contributions of notes held by the related medical group. ${ }^{11}$ This illustration of the meaning of the phrase "held itself out to the public . . . as a charitable institution" is most important. The court evidently does not regard a hospital as holding itself out as a charitable institution because it advertises itself as a purveyor of free care. Rather, a hospital, under the Harding Hospital case, "holds itself out to the public as a charitable institution" by soliciting charitable contributions from the public. ${ }^{12}$ Thus, any tax exempt hospital which continues to receive con-

108. 505 F.2d at 1076 .

109. 505 F.2d at 1077 (emphasis added).

110. Id.

111. Id.

112. See Id. 
tributions from representative members of the general public should be deemed to be holding itself out to the public as a charitable institution within the meaning of the Harding decision.

2. The hospital did not have a specific plan or policy for the treatment of charity patients. The discussion of this factor is perhaps the most unfortunate part of this decision. The court apparently did not consider the modus operandi of American hospitals in the 1970s, particularly the fact that Medicare, Medicaid, and health insurance now provide funds for services rendered to most patients, including indigent patients. The court never addressed itself to the vital question of where a volume of patients requiring free care were to be found nor where a hospital is to obtain the funds to finance the care of such patients. Furthermore, there is evidence that Harding Hospital did, in fact, treat patients without charge. The decision further indicates that when the funds of previously admitted patients were exhausted, the hospital did "treat them on a charitable basis." The ratio of uncompensated services to total revenue at the hospital ranged from 4.2 per cent to 7.8 per cent for the years in question. The court admits that these figures "are higher than those for some other area hospitals and those for which exemption has been denied."113

Based upon many years of experience in dealing with the issue of tax exemption of nonprofit hospitals, including consideration of the average levels of free care provided, this author finds the court's treatment of 4.2 per cent to 7.8 per cent charity care as insufficient evidence of a policy of admission and treatment of charitable patients unrealistic and anachronistic. In the Harding Hospital case, there is no evidence that the hospital followed a policy of turning away patients unable to pay. The court thus appears to be saying that the mere fact that the hospital does not seek out patients for whom reimbursement is not available under Medicare, Medicaid, and private health insurance is prima facia evidence of a lack of a policy or program for treatment of charity patients. While this may be a factor in determining whether the hospital is operated for the maxium economic benefit of a small related medical group, under current methods of financing hospital care, such factor has little meaning.

The remaining three factors, and the ones which the decision really turns upon, relate to the private benefit derived by the medical group. Factor (3) relates to the fact that since the doctors who are members of the associates of the medical group treated between 90 per cent and 95 per cent of the patients admitted to this hospital, "they derived substantial benefit for the existence and the operation of the Hospital."114 As the court pointed out, "this

113. Id.

114. 505 F.2d at 1078. Section 501(c)(3) provides in part that "no part of the net earnings of 
virtual monopoly by the Associates of the patients permitted benefits to inure to the Associates within the intendment of the statute."115

Factor (4) goes to the fact that the medical group benefited from an agreement with the hospital whereby the associates were not adequately compensating the hospital for the use of equipment and business office services.

Factor (5) relates to the medical groups receiving a private benefit from an agreement with the hospital under which they were paid by the hospital for hospital supervision. Thus, the discussion of charitable care contained in factors (1) and (2) of the Harding Hospital case must be read in the limited context in which they are set, i.e., as evidence of private benefit which is incompatible with exemption under section 501 (c)(3).

In summation, the Harding Hospital case provides a good illustration of the importance of considering the financing of health care upon the tax exempt status of nonprofit hospitals. While one cannot quarrel with the conclusion reached by the Sixth Circuit in view of the presence of private benefit, thought must be given as to how this decision will be applied in future years when national health insurance provides funds to enable all indigents to receive hospital care. If the tax law does not properly take into account the economic and social changes in the financing of health care, these laws will invariably have an adverse effect on our hospitals and their ability to serve the public.

which inure to the benefit of any private shareholder or individual." Further, Treas. Reg. $\S 1.501(\mathrm{c})(3)-\mathrm{l}(\mathrm{d})(2)(\mathrm{iii})$ provides that:

[A]n organization is not organized or operated exclusively for one or more charitable purposes... unless it serves the public rather than a private interest. Thus to meet the requirements of this subdivision, it is necessary for an organization to establish that it is not organized or operated for the benefit of private interest such as designated individuals, the creator or its family, shareholders of the organization or persons, controlled, directly or indirectly, by its subscribing interests.

115. Id. 